\title{
RANCANG BANGUN SISTEM INFORMASI PEMERINTAHAN DESA UNTUK PENINGKATAN PELAYANAN BERBASIS WEB DAN ANDROID
}

\author{
Yati Nurhayati ${ }^{1}$, Fauziah $^{2}$ \\ ${ }^{1,2}$ Fakultas Ilmu Komputer Universitas Kuningan \\ E-mail: $*^{1}$ yati.nurhayati@ uniku.ac.id, ${ }^{* 2}$ fauziah@ uniku.ac.id
}

\begin{abstract}
Abstrak
Penelitian ini dibangun untuk membantu pemerintahan desa untuk mengelola data yang terdapat di desa tersebut, dikarenakan selama ini pengelolaan data yang ada masih dilakukan secara semi-manual serta belum terintegrasi sehingga menyulitkan bagi pihak-pihak yang membutuhkan informasi tersebut. Pada penelitian ini, data yang diolah adalah data desa (sejarah, visi misi, struktur organisasi, alamat, foto kantor, peta desa), data sumber daya desa (data desa, data sumber daya alam, data asset desa), data RAB (rancangan anggaran belanja), data berita dan kegiatan desa. Serta masyarakat dapat mengirimkan permohonan pembuatan surat menggunakan android, yang nantinya oleh admin desa akan diproses dan hasilnya diupload ke sistem serta masyarakat sehingga kerentanan hilangnya surat dapat diminimalisir serta mengefisienkan waktu. Agar sistem yang dihasilkan optimal, maka sistem dirancang menggunakan UML (United Modeling Language) serta diimplementasikan ke dalam Bahasa pemrograman php, mysqli dan android. Hasil akhir dari penelitian ini berupa sebuah sistem yang dapat mengelola data di pemerintahan desa serta dapat membantu pemerintahan desa dalam meningkatkan pelayanan ke masyarakat.
\end{abstract}

Kata Kunci : Desa, $P H P M y S Q L$, Android.

\begin{abstract}
This research was built to help the village government to manage the data contained in the village, because so far the existing data management is still done semi-manually and has not been integrated, making it difficult for those who need the information. In this study, the data processed are village data (history, vision and mission, organizational structure, addresses, office photos, village maps), village resource data (village data, natural resource data, village asset data), RAB data (design budget), data on news and village activities. And the community can send a request for making letters using android, which will be processed by the village admin and the results will be uploaded to the system and the community so that the vulnerability of the loss of letters can be minimized and make time efficient. So that the resulting system is optimal, the system is designed using UML (United Modeling Language) and implemented in the PHP, mysqli and android programming languages. The final results of this study are in the form of a system that can manage data in the village administration and can assist village governments in improving services to the community.
\end{abstract}

Keywords: Village, PHP MySQLi, Android.

\section{PENDAHULUAN}

Desa merupakan salah satu roda penggerak pemerintahan terkecil tetapi memiliki peranan besar karena berhubungan langsung dengan masyarakat.
Berdasarkan Peraturan Menteri No. 84 tahun 2015, Desa adalah desa dan desa adat atau yang disebut dengan nama lain, selanjutnya disebut Desa, adalah kesatuan masyarakat hukum yang memiliki batas wilayah yang berwenang untuk mengatur 
JURNAL BUFFER INFORMATIKA

Volume 5 Nomor 2, Oktober 2019

dan mengurus urusan pemerintahan, kepentingan masyarakat setempat berdasarkan prakarsa masyarakat, hak asal usul, dan/atau hak tradisional yang diakui dan dihormati dalam sistem pemerintahan Negara Kesatuan Republik Indonesia.[1] Menurut Fatansyah (2004), Web merupakan system informasi terdistribusi yang berbasis hypertext. Dokumendokumen yang dikelola dalam web bias beraneka jenis (pengolah kata, lembar kerja, tabel berbasis data, presentasi, hypertect dan lain-lain) dan beragam format (.doc, .pdf, .xls, .ppt, .htm).[2]

Salah satu desa yang memiliki Anggaran Pendapatan dan Belanja Daerah (APBD) yang besar di daerah kabupaten kuningan provinsi jawa barat adalah desa ciputat kecamatan ciawigebang. Adapun permasalahannya adalah pengelolaan data di desa masih dilakukan secara semi manual, belum adanya aplikasi khusus untuk menangani pengelolaan tersebut sehingga tidak efisien waktu, pelaporan dan tingkat pelayanan kepada masyarkat menjadi kurang optimal.

Data yang dikelola oleh pemerintahan desa antara lain pengelolaan data penduduk yang masih dikerjakan dalam bentuk excel dan ditempel di kantor desa, ketika ada pihak yang membutuhkan data harus datang ke kantor desa sehingga tidak efisien waktu. Untuk pembuatan surat menyurat pun, file harus dicari terlebih dahulu di dalam komputer kemudian dilakukan proses editing serta nomor surat harus dituliskan manual di buku besar sehingga tidak optimal.

Belum adanya system yang mengintegrasikan berbagai informasi yang dimiliki oleh pemerintahan desa, sehingga ketika pihak lain membutuhkan informasi mengalami kesulitan sebab data hanya dimiliki oleh seorang pegawai saja, contoh ketika tim PKK (Pendidikan kesejahteraan keluarga) membutuhkan data, mereka harus melakukan rekapitulasi kembali dari dokumen-dokumen yang ada yang hanya dimiliki oleh kasi kesra, sedangkan untuk data penduduk mereka harus meminta data kepada kaur umum, sehingga hal ini tidak efisien karena pekerjaan harus dilakukan
p-ISSN : 2527-4856, e-ISSN : 2614-5413

https://journal.uniku.ac.id/index.php/buffer

berulang kali dan harus menghubungi pihak-pihak yang berbeda.

Untuk mengatasi permasalahan di atas maka dibutuhkan sebuah sistem yang dapat membantu pemerintah desa untuk meningkatkan pelayanan kepada masyarakat, sehingga penulis mengambil judul penelitian "Rancang Bangun Sistem Informasi Pemerintahan Desa Untuk Peningkatan Pelayanan Berbasis Web dan Android"

\section{METODE PENELITIAN}

Tahapan kerangka pemikiran dapat dilihat pada Gambar 1

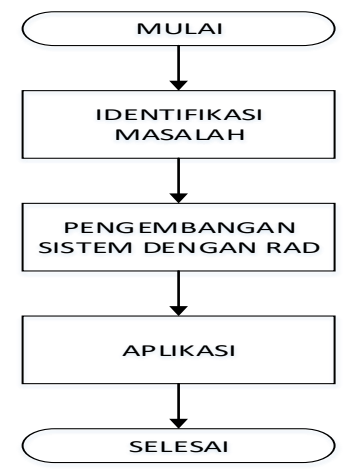

Gambar 1. Tahapan Kerangka Pemikiran

\subsection{Rapid Aplication Development $(R A D)$}

Rapid Application Development (RAD) adalah salah satu alternatif dari System Development Life Cycle digunakan untuk mengatasi keterlambatan dalam proses development.

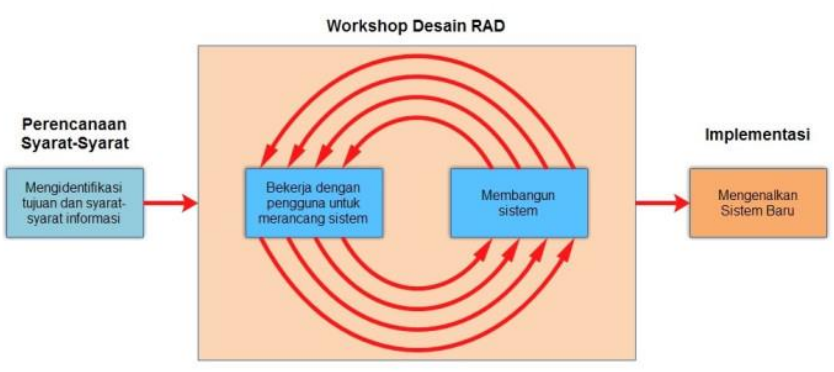

Gambar 2. Tahapan RAD (Kendall, 2010). 
JURNAL BUFFER INFORMATIKA

Volume 5 Nomor 2, Oktober 2019

Adapun tahapan dari RAD adalah [5] :

a. Requirement Planning

Pada tahapan ini pengguna dan penganalisis bertemu untuk mengidentifikasikan tujuan aplikasi atau system serta untuk mengidentifikasikan syarat-syarat informasi yang ditimbulkan dari tujuan-tujuan tersebut. Orientasi dari tahap ini adalah menyelesaikan masalah-masalah perusahaan.

b. RAD Design Workshop (Workshop Desain RAD)

Fase ini adalah fase untuk merancang dan memperbaiki yang bisa digambarkan sebagai workshop. Penganalisis dan dan pemrogram dapat bekerja membangun dan menunjukkan representasi visual desain dan pola kerja kepada pengguna.

c. Implementasi (Implementation)

Pada fase implementasi ini, penganalisis bekerja dengan para pengguna secara intens selama workshop dan merancang aspekaspek bisnis dan nonteknis perusahaan.

\subsection{Teknik Pengumpulan Data}

Teknik pengumpulan data yang digunakan dalam penelitian ini adalah :

a. Observasi

Untuk mengetahui sistem yang sedang berjalan di desa dan permasalahannya, maka pada penelitian ini dilakukan pengamatan secara langsung khususnya pada saat masyarakat melakukan pengajuan pembuatan surat ke desa.

b. Studi Pustaka

Pada teknik ini, data dikumpulkan dengan mempelajari berbagai dokumen, jurnal dan beberapa literature lainnya yang berkaitan dengan permasalahan yang diteliti mengenai pengolahan data di desa serta mengenai Bahasa pemograman php mysqli dan android.
p-ISSN : 2527-4856, e-ISSN : 2614-5413

https://journal.uniku.ac.id/index.php/buffer

c. Wawancara

Selain studi pustaka, data juga diperoleh dengan melakukan sesi Tanya jawab dengan pihak-pihak yang berkaitan secara langsung dengan objek penelitian yaitu dengan kasi pemerintahan desa ciputat, ibu-ibu PKK dan perangkat desa lainnya.

\section{$2.3 U M L$}

Menurut Sukamto dan Shalahuddin (2014:133), "UML (Unified Modelling Language) adalah salah satu standar bahasa yang banyak digunakan di dunia industri untuk mendefinisikan requirement, membuat analisis dan desain, serta menggambarkan arsitektur dalam pemrograman berorientasi objek.

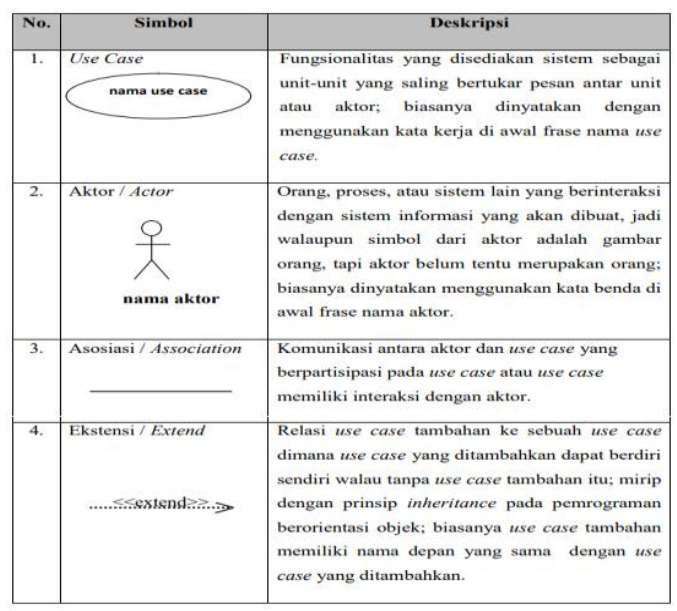

Gambar 3 Use Case Diagram

\section{HASIL DAN PEMBAHASAN}

Adapun hasil dan pembahasan dari penelitian ini adalah:

a. Requirement Plannning

Tahap pertama metodologi RAD adalah requirement planning dimana pada tahapan ini diperoleh informasi kebutuhan system secara fungsional dan non fungsional :

- Analisa Kebutuhan Sistem Fungsional

Adapun hasil Analisa kebutuhan sistem yang diperoleh dapat dilihat pada tabel 1 . 
JURNAL BUFFER INFORMATIKA

Volume 5 Nomor 2, Oktober 2019

Tabel 1. Kebutuhan Admin Desa

\begin{tabular}{|c|c|c|}
\hline No & Fungsi & $\begin{array}{l}\text { Hak } \\
\text { Akses }\end{array}$ \\
\hline 1. & $\begin{array}{l}\text { Kelola data desa (sejarah, } \\
\text { visi misi, struktur } \\
\text { organisasi, alamat, foto } \\
\text { kantor, peta desa), data } \\
\text { sumber daya desa (data } \\
\text { desa, data sumber daya } \\
\text { alam, data asset desa), } \\
\text { data RAB (rancangan } \\
\text { anggaran belanja), data } \\
\text { berita dan kegiatan desa }\end{array}$ & CRUD \\
\hline 2. & Surat & $\mathrm{RU}$ \\
\hline 3. & Kritik dan Saran & RUD \\
\hline
\end{tabular}

Tabel 2 Kebutuhan Masyarakat

\begin{tabular}{|l|l|l|}
\hline No & Fungsi & $\begin{array}{l}\text { Hak } \\
\text { Akses }\end{array}$ \\
\hline 1. & $\begin{array}{l}\text { Kelola data desa (sejarah, } \\
\text { visi misi, struktur } \\
\text { organisasi, alamat, foto } \\
\text { kantor, peta desa), data } \\
\text { sumber daya desa (data } \\
\text { desa, data sumber daya } \\
\text { alam, data asset desa), } \\
\text { data RAB (rancangan } \\
\text { anggaran belanja), data } \\
\text { berita dan kegiatan desa }\end{array}$ & \\
\hline 2. & Surat & CR \\
\hline 3. & Kritik dan Saran & CR \\
\hline
\end{tabular}

- Analisa Kebutuhan Non Fungsional Adapun analisa kebutuhan non fungsional dapat dilihat pada tabel 2 dan 3.

Tabel 3 Kebutuhan Pembangunan Aplikasi

\begin{tabular}{|l|ll|ll|}
\hline No & \multicolumn{2}{|c|}{ Hardware } & \multicolumn{2}{c|}{ Software } \\
\hline 1. & a. & PC Laptop & a. & Microsoft \\
& b. & RAM 3 Gb Go & & Windows \\
& c. & HDD 120 Gb & b. & Adobe \\
& d. & Mouse & & Dreamw \\
& e. & Printer & & eaver \\
& f. & Flash disk & & CS5 \\
& & & c. & XAMPP \\
& & d. & 1.8 .4 \\
& & & Google \\
& & & & Chrome \\
\hline
\end{tabular}

p-ISSN : 2527-4856, e-ISSN : 2614-5413

https://journal.uniku.ac.id/index.php/buffer

Tabel 4 Kebutuhan Implementasi Aplikasi

\begin{tabular}{|c|c|c|c|}
\hline No & Kebutuhan & $\begin{array}{c}\text { Komputer } \\
\text { Server }\end{array}$ & $\begin{array}{c}\text { Komputer } \\
\text { Client }\end{array}$ \\
\hline 1. & Hardware & $\begin{array}{l}\text { a.PC Core i7 } \\
\text { b.RAM } 4 \text { Gb } \\
\text { c. HDD } 240 \\
\text { Gb } \\
\text { d.Mouse } \\
\text { e. Keyboard } \\
\text { f. Monitor } \\
\text { LCD 21' } \\
\text { g.Printer }\end{array}$ & $\begin{array}{l}\text { a. PC Dual } \\
\text { Core, } 2 \mathrm{Ghz} \\
\text { b. RAM 2Gb } \\
\text { c. HDD } \\
\text { 120Gb } \\
\text { d. Mouse } \\
\text { e. Keyboard } \\
\text { f. Monitor } \\
\text { LCD 14' } \\
\text { g. Printer } \\
\text { h. Barcode } \\
\text { Scanner }\end{array}$ \\
\hline 2. & Software & $\begin{array}{l}\text { a. Windows } 7 \\
\text { b. Xampp } \\
1.8 .4 \\
\text { c. Google } \\
\text { Chrome }\end{array}$ & $\begin{array}{l}\text { a. Windows } 7 \\
\text { b. Google } \\
\text { Chrome }\end{array}$ \\
\hline
\end{tabular}

b. UML

Adapun perancangan system dalam penelitian ini menggunakan UML, yaitu:

- Use Case Diagram

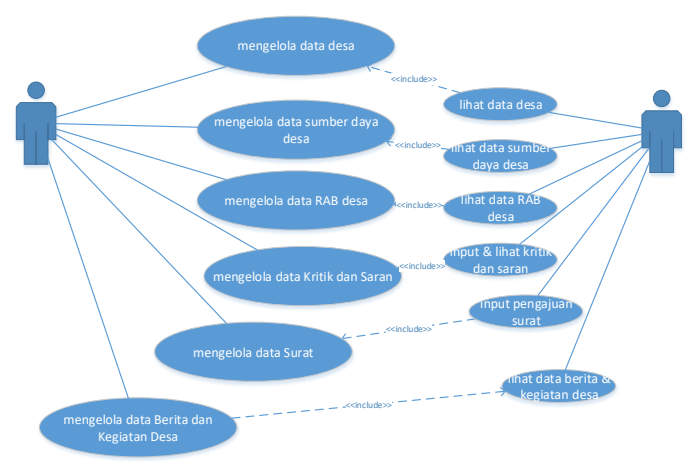

Gambar 4 Use Case Diagram

- Activity Diagram

Pengelolaan data desa (sejarah, visi misi, struktur organisasi, alamat, foto kantor, peta desa), data sumber daya desa (data desa, data sumber daya alam, data asset desa), data RAB (rancangan anggaran belanja), data berita dan kegiatan desa 
JURNAL BUFFER INFORMATIKA

Volume 5 Nomor 2, Oktober 2019

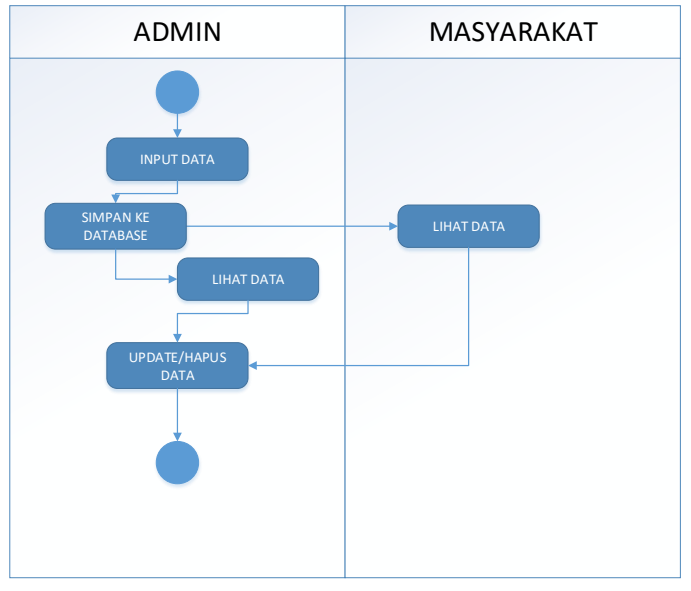

Gambar 5 Activity Diagram Data Utama

Pengelolaan Data Surat

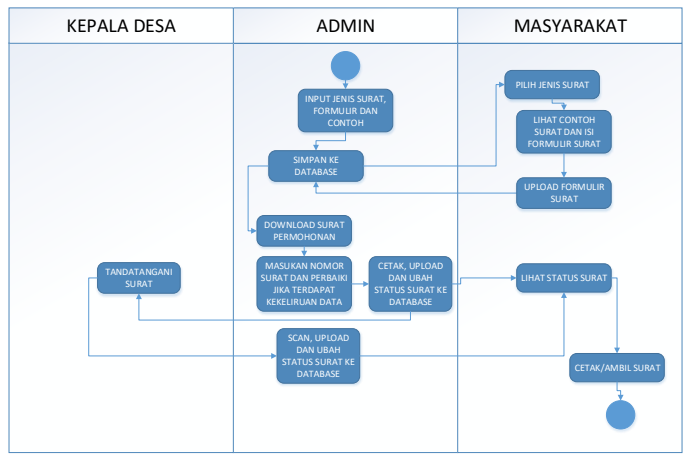

Gambar 6 Pengelolaan Data Surat

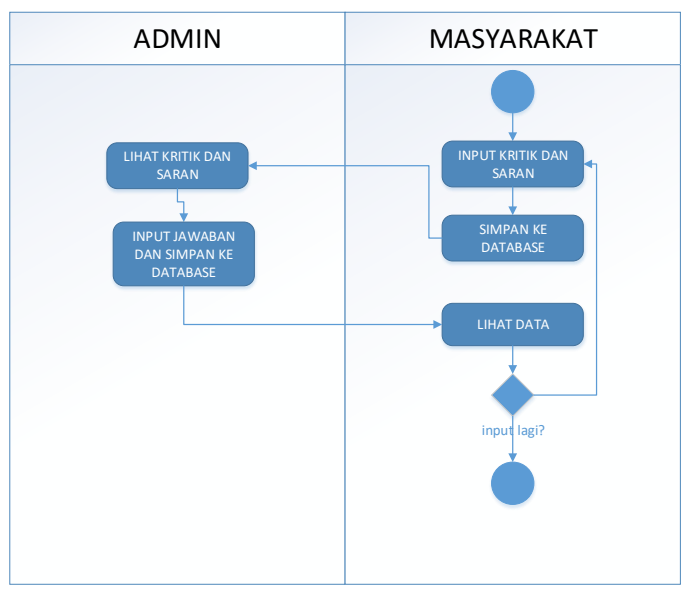

Gambar 7 Pengelolaan Data Kritik dan Saran
p-ISSN : 2527-4856, e-ISSN : 2614-5413

https://journal.uniku.ac.id/index.php/buffer

- Class Diagram

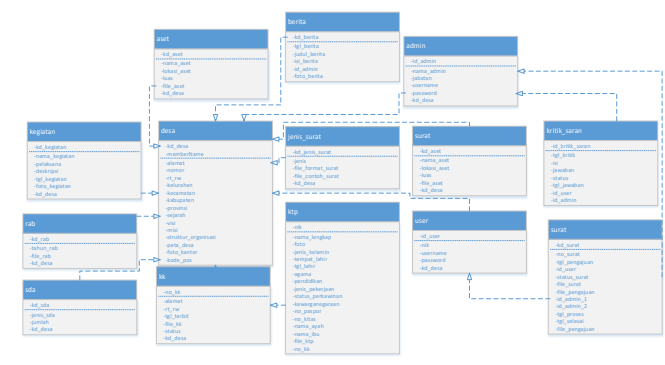

Gambar 8 Class Diagram

c. Implementasi

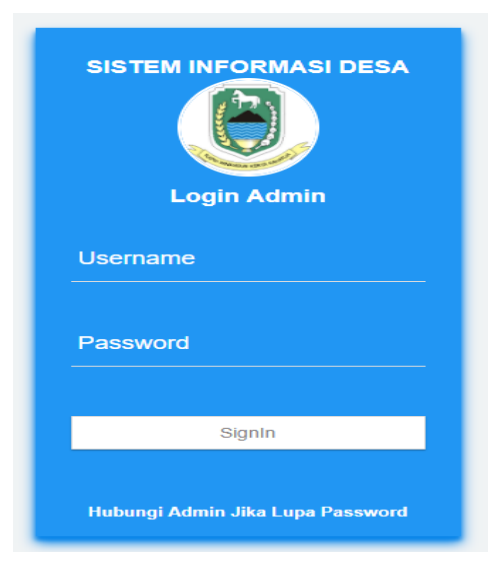

Gambar 9 Login

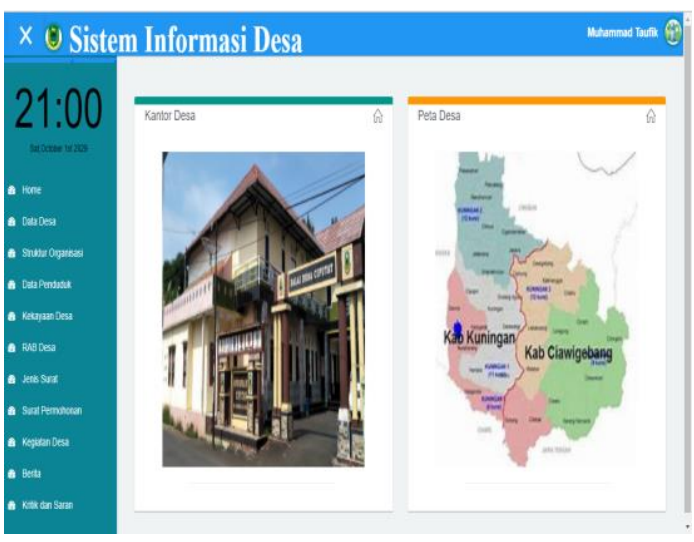

Gambar 10 Halaman Utama Admin 
JURNAL BUFFER INFORMATIKA

Volume 5 Nomor 2, Oktober 2019

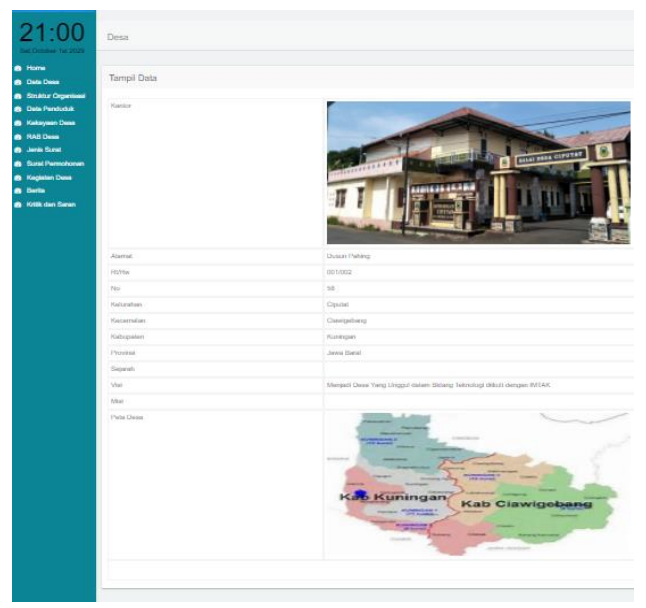

Gambar 11 Halaman Data Desa

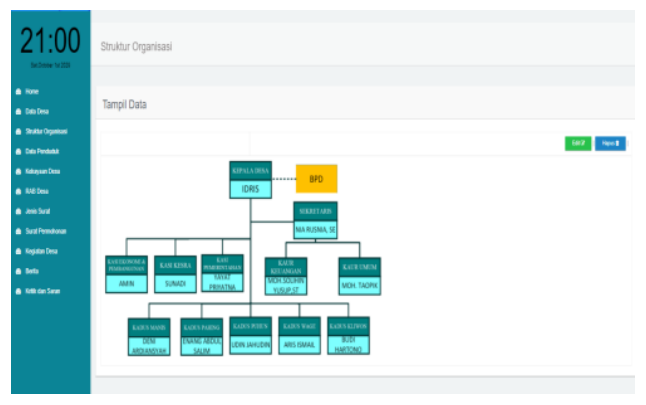

Gambar 12 Struktur Organisasi

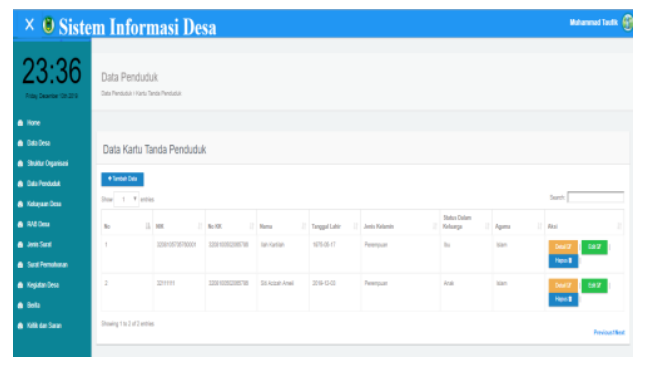

Gambar 13 Kartu Tanda Penduduk

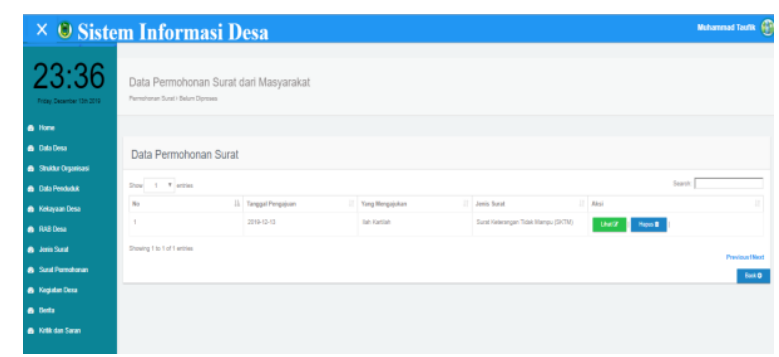

Gambar 14 Data Surat Permohonan Yang Baru Masuk
p-ISSN : 2527-4856, e-ISSN : 2614-5413

https://journal.uniku.ac.id/index.php/buffer

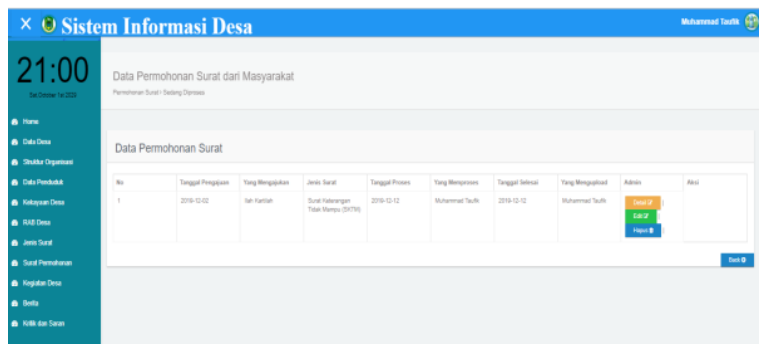

Gambar 15 Data Surat Permohonan Yang Telah Selesai diproses

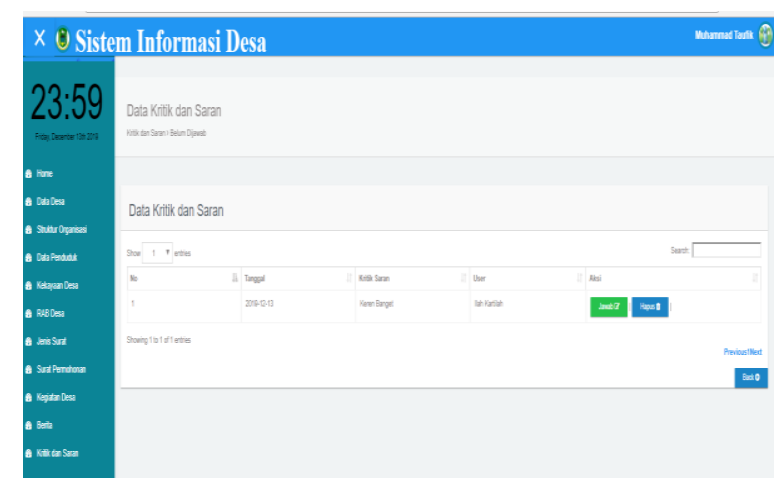

Gambar 16 Kritik dan Saran yang Baru Masuk

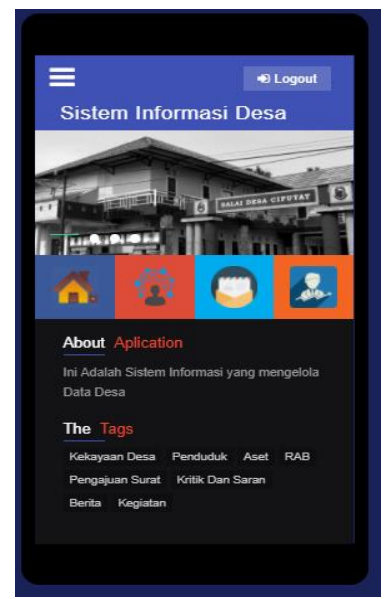

Gambar 17 Halaman Utama 
JURNAL BUFFER INFORMATIKA

Volume 5 Nomor 2, Oktober 2019

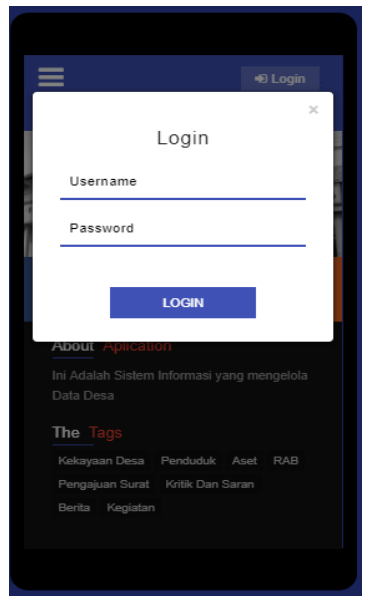

Gambar 18 Halaman Login

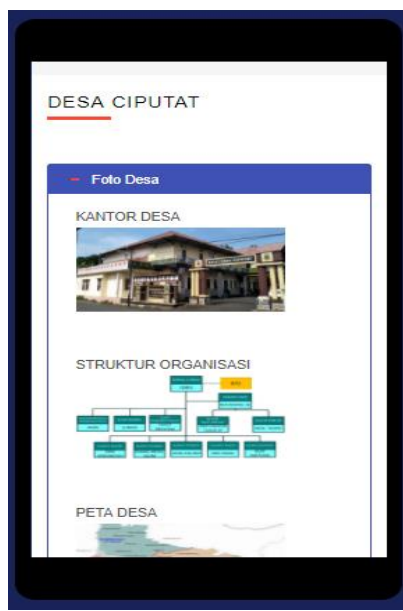

Gambar 19 Halaman Informasi Desa

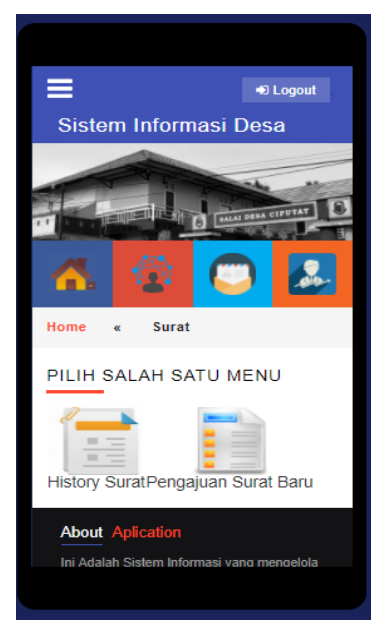

Gambar 20 Menu Surat
p-ISSN : 2527-4856, e-ISSN : 2614-5413

https://journal.uniku.ac.id/index.php/buffer

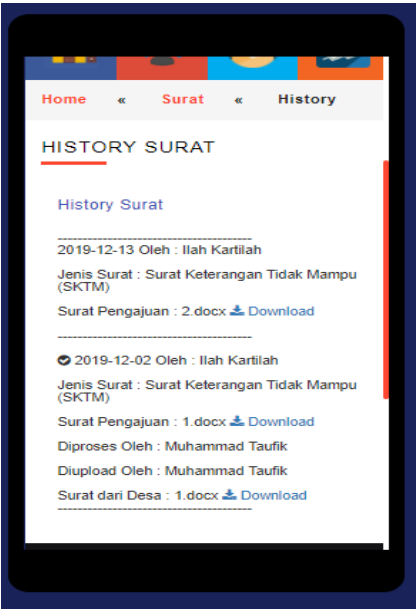

Gambar 21 Halaman History Surat

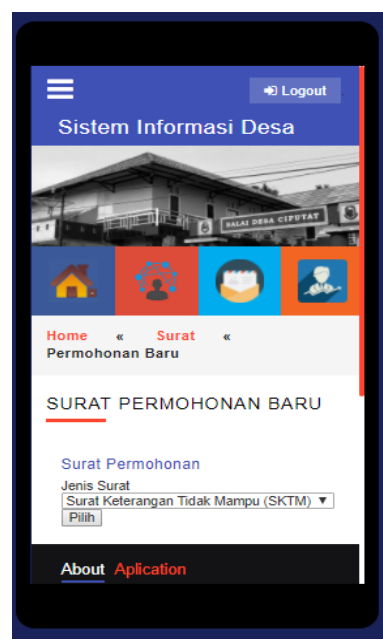

Gambar 22 Pilih Jenis Surat yang Ingin Diajukan

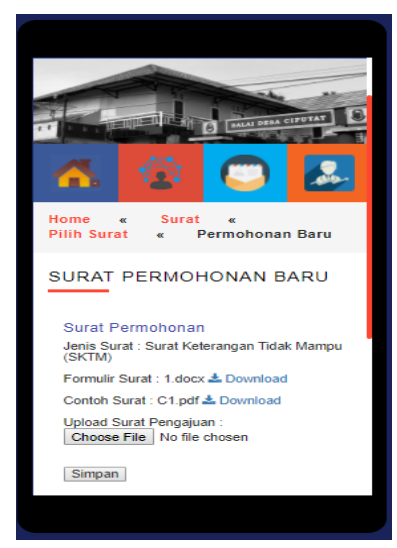

Gambar 23 Halaman Pengisian Formulir Surat 
JURNAL BUFFER INFORMATIKA

Volume 5 Nomor 2, Oktober 2019

\section{KESIMPULAN}

Penelitian ini berhasil mengelola data pada desa ciputat yang meliputi: data desa (sejarah, visi misi, struktur organisasi, alamat, foto kantor, peta desa), data sumber daya desa (data desa, data sumber daya alam, data asset desa), data RAB (rancangan anggaran belanja), data berita dan kegiatan desa.

Masyarakat/user dapat mengirimkan pengajuan untuk pembuatan surat ke desa secara langsung menggunakan android.

Dengan menggunakan sistem yang terintegrasi memudahkan seluruh pihak untuk memperoleh informasi secara cepat dan optimal.

\section{SARAN}

Agar penelitian yang dihasilkan lebih optimal, maka diharapkan : Tools dapat dikembangkan berbasis Android agar lebih memudahkan lagi

\section{UCAPAN TERIMA KASIH}

Penulis mengucapkan terima kasih kepada LPPM Universitas Kuningan yang telah memberi dukungan terhadap penelitian ini serta LLDIKTI yang telah membantu secara finansial dalam penelitian ini.

Serta penulis mengucapakan terima kasih kepada pemerintahan Desa Ciputat Kecamatan Ciawigebang Kabupaten Kuningan yang telah membantu dalam pengumpulan data penelitian.

\section{DAFTAR PUSTAKA}

[1]. Indonesia, Republik. 2015. Peraturan Menteri No. 84 tahun 2015 tentang Susunan Organisasi Dan Tata Kerja Pemerintahan Desa. Jakarta : Menteri Dalam Negeri Republik Indonesia, 2015
p-ISSN : 2527-4856, e-ISSN : 2614-5413

https://journal.uniku.ac.id/index.php/buffer

[2]. Sukamto, Rosa A. M,Shalahuddin. 2014. Rekayasa Perangkat Lunak Terstruktur dan Berorientasi Objek. Bandung : Informatika, 2014

[3]. Fatansyah. 2004. Buku Teks Komputer Sistem Basis Data (Lanjutan Buku Basis Data). Informatika Bandung: Bandung.

[4]. Kendall, Kenneth E dan Kendall, Julie E. 2010. Systems Analysis And Design. Pearson Education Inc: New Jersey. 